Norfolk varied between north-east and south-east, sometimes on successive nights, so that, according to the night on which they happened to travel, the migrants might make their landfall anywhere between mid-Denmark and Belgium, some 400 miles apart. It is at this juncture, presumably, that their sense of geographical position comes into play. That birds possess such a capacity is shown not only by homing experiments ${ }^{4,6}$ but also by the fact that various drifted migrants trapped and ringed in Britain have later been recovered in their normal Continental wintering or breeding grounds well to the east, and Williamson has rightly stressed the importance of such re-directed movements. Indeed, it may be claimed that the homing sense, now demonstrated in many species of birds, is primarily an adaptation to counteract drift, which the present observations show to be a normal accompaniment of migration.

The observations in Table 3 refer to directions over the sea. Many fewer directions were observed over the land in Norfolk, but these followed the same general trends, the birds travelling south of east with northerly winds and north of east with southerly winds. Hence migrational drift also occurs over the land, though if the birds fly lower when over the land than over the sea, their drift will be smaller, since the wind is normally weaker nearer the ground. These remarks, it should be added, refer only to those migrants flying high enough over the land to be detected by radar, and not to those flying low by day, which may follow the coast or other 'guiding lines'.

While, as shown here, migrational drift is regular in fine or moderately fine weather, Williamson and others have found that drifted migrants land in large numbers at the British east-coast bird observatories primarily when they must have met wholly overcast conditions during the course of their journey. Under such conditions, birds can no longer see to navigate by the Sun or stars. Moreover, as is well known, they do not normally set off on their migrations in such weather, hence the spring departure from Norfolk normally provides unsuitable conditions for studying what happens. However, in clear weather on the afternoon of April 17, 1958, many redwings and other species took off rather north of east, and soon after dark, mist and rain became general. Rain echoes came to obscure most of the plan-position display, but one gap remained well out to sea, and here, between 2030 and $2130 \mathrm{hr}$., I had quite unusual difficulty in establishing the directions of the birds from the afterglow of the echoes. In one period, for example, there seemed to be twenty-one directions scattered fairly evenly between north.north-east and south-east, and eleven others between south-southwest and north-north-west; but the afterglow was normally short, and soon afterwards the directions often seemed to have changed. Yet only three hours earlier, in fine weather, there were many sustained tracks in a nearly constant direction north of east, and the same applied once more when the rain cleared off in the early morning. Presumably, during the period of fully overcast conditions, the birds could not maintain their heading, and flew around irregularly with repeated changes of direction.

It is hoped to study such conditions more fully later ; but provisionally the radar evidence suggests that migrants meeting fully overcast skies over the sea fly around irregularly and indecisively, in which case their eventual direction will be that of the wind at the time. Further, they are likely under these conditions to become extremely tired, and so will tend to alight at the first land encountered. With normal drift in fine weather, on the other hand, migrants reaching the coast seem usually to proceed some way farther before settling, and so are not concentrated at the point of arrival. Hence it is primarily when migrants meet overcast conditions that they later appear in large numbers at the British bird observatories.

I am extremely grateful to the Air Ministry and to the Research Branch, Fighter Command, for allowing me full facilities for this work, and to Mr. W. G. Harper, of the Meteorological Office, East Hill, who is also working on birds and radar? ${ }^{7}$, for most helpful discussions. The pioneer work in this field of E. Sutter ${ }^{8}$ was an invaluable spur.

${ }^{1}$ Baxter, E. V., and Rintoul, L. J., Ibis, 251 (1918).

${ }^{2}$ Ritchie, J., Proc. Roy. Soc. Edin., 60, 299 (1940).

${ }^{3}$ Williamson, K., Act. Cong. Int. Orn., 11, 179 (1955).

'Kramer, G., Ibis, 99, 196 (1957).

${ }^{5}$ Sauer, F'. and E., Rev. Suisse Zool., 62, 250 (1955).

"Matthews, G. V. T., "Bird Navigation" (Camb. Univ, Press, 1955).

${ }^{7}$ Harper, W. G., Nature, 180, 847 (1957).

${ }^{8}$ sutter, E., Orn. Beob., 54, 70 (195i).

\title{
OBITUARIES
}

\section{Prof. C. H. Desch, F.R.S.}

No one could come in contact with Cecil Henry Desch, who died on June 19 at the age of eighty-four, without being influenced by his astounding knowledge and complete sincerity. Educated at Birkbeck School, Finsbury Technical College and University College, London, as a chemist, he then went to Würzburg, where he obtained his doctorate.

After being connected with the brewery and cement industries for a short time, he joined the Metallurgical Department of King's College, London, in 1902, and it was during this time that much of the work on his book on "Metallography" was done. In the preparation of this volume he was greatly indebted to Mrs. Desch for the preparation of the beautiful microsections with which it was illustrated. The influence of this book on English metallurgy was immense. In many ways it broke new ground, and it may be that this represents his greatest influence on metallurgical science, in any event in Great Britain.

In 1909 , Desch was appointed to the Graham Young lectureship in metallurgical chemistry in the University of Glasgow, remaining there until the end of the First World War, when he was appointed to the chair of metallurgy at the Royal Technical College in that city. His tenure of this chair was short (1918-20), and on the retirement of Arnold he succeeded him in the chair of metallurgy in the University of Sheffield. His twelve years in this chair saw immense changes and the beginning of the modernization which was inevitable if its reputation was to be maintained, and it was during this time that $I$ knew him best. It was not an easy job to follow Arnold and to make the changes in the existing course which Desch saw to be essential, and those in closest scientific contact with 
him must have wondered whether this post was really congenial.

In 1932 he resigned his chair, to follow Rosenhain as superintendent of the Department of Metallurgy at the National Physical Laboratory, remaining there until his retirement, in 1939.

Desch's next appointment must have surprised most of those who knew him, for in the November of that year he was appointed, by Securities Management Trust Ltd., to the board of Richard Thomas and Co., Ltd. In 1943 he resigned, on appointment as chief scientific adviser to the Whitehead Iron and Steel Co., Ltd. This complete change from acadernic to industrial life, however, seemed to give him real satisfaction. It was not his first experience of industry, and the possibility of applying his wide knowledge to the industrial needs of the country at a critical time was compatible with his life-long interest in sociological problems. These had, I believe, at an earlier date led him to become somewhat republican in his political thought, though this changed later, when he again became (mildly) royalist.

Desch's quite outstandingly successful book on metallography was followed, in 1914, by one on "Intermetallic Compounds". Despite all the changes which have taken place in the intervening years, this is still a book which may be read with profit, and was, when first published, of the greatest interest. In addition, and largely as a result of the visit paid, in 1931, to the United States of America, where he was the George Fisher Baker Lecturer at Cornell University, he published one of the earlier books on the solid state, the "Chemistry of Solids", largely based on the lectures which he gave there.

Over a number of years he was greatly interested in early metallurgy, as a result of which a number of reports were submitted to the British Association on the source of metals used by the Sumerians and other ancient peoples.

Elected to the Royal Society in 1923, he was president of the Faraday Society during 1926-28 and received the Bessemer Gold Medal from the Iron and Steel Institute and the Platinum Medal of the Institute of Metals, both the highest distinctions which these Institutes have it in their power to confer.

It was as a teacher, however, that Desch probably reached his highest level. He was an excellent lecturer, and the width of his knowledge enabled him to weave together facts and ideas obtained from an almost unique variety of sources. His mind was not strikingly original and his researches in metallurgy did not make any very lasting mark on its development.

This account of his scientific life and the important posts which he held gives, however, an inadequate description of the man himself. His complete sincerity of thought and his interest in human needs in general have already been mentioned. Among his relaxations was his interest in geology, a fact which led to his very good Sorby Lecture, delivered in 1921. His somewhat shambling gait was characteristic, but it carried him over many miles of rough country.

F. C. THOMPSON

\section{Mr. H. E. Balch}

Mr. H. E. BALCH, honorary curator of the museum at Wells, Somerset, for sixty-one years, died on May 27 at the advanced age of eighty-eight.

Starting life as a messenger in the Post Office and finally rising to the position of head postmaster at Wells, he devoted the whole of his leisure time to the exploration of the Mendip Hills, and this in spite of the long hours of duty involved in his work. In 1893 he started a museum of his own material in the West Cloister of Wells Cathedral. An ardent collector himself, he soon persuaded others to give, and in 1928, through the generosity and interest of $\mathrm{Mr}$. William Wyndham, the Museum was moved to a large house in the Cathedral Green. He was made chairman of the Trustees for life and honorary curator, a position he held until his retirement in 1954.

Balch had many publications to his credit, his major work undoubtedly being the large monograph on the excavations at Wookey Hole. He was awarded the honorary degree of master of arts in the University of Bristol in 1925 and was presented with the freedom of the City of Wells in 1944. He will be remembered with affection by many for his devotion and zeal to the elucidation of the problems of Mendip and for the amassing of such valuable collections which now and for the future will form the basis of the important museum at Wells. F. S. WALLIS

\section{NEWS and VIEWS}

Ministry of Supply Electronics Research and Development (Telecommunications): Mr. R. G. Friend

MR. R. G. FrIEND, who has been appointed director of electronics research and development (telecommunications) in the Ministry of Supply, read physics at Queens' College, Cambridge, where he was a Foundation Scholar and took first-and second-class honours in the two parts of the Natural Science Tripos. He then joined the Research Department, Woolwich Arsenal, where for some years he was engaged on research on X-ray and magnetic methods of material testing. In 1935, he transferred to the Air Defence Experimental Establishment for acoustical research with particular reference to the development of a new sound locator using electrical delay lines. Early in 1939, Mr. Friend was selected to move to Bawdsey to join a small team working with Sir Robert Watson-Watt on the application of the new radar techniques to Army problems. On the outbreak of war, this team moved to Christ. church, where it expanded and ultimately became the Radar Research and Development Establishment. Throughout the Second World War, Mr. Friend continued in this work and was responsible for many contributions in the fields of radar fire control for anti-aircraft guns and of counter-measures to radar jamming. He was for some years in charge of the Fire Control Group and later the Basic Techniques Research Group. In 1954 he moved to the headquarters of the Ministry of Supply on appointment as assistant director of electronics research and development. In this post, and later as acting director, he has been responsible for the research and development aspects of all ground radar for both the R.A.F. and Army applications. 